\title{
Effect of Leaf Characteristics on Different Brinjal Genotypes and their Correlation on Insects Pests Infestation
}

\author{
S.P. Bindu* and A. Pramanik \\ Department of Agricultural Entomology, Bidhan Chandra Krishi Viswavidyalaya, \\ Mohanpur - 741 252, West Bengal, India \\ *Corresponding author
}

\section{A B S T R A C T}

\begin{tabular}{|l|l|l|l|l}
\hline Keyw ords & $\begin{array}{l}\text { The field and laboratory experiments were carried out with twenty-two brinjal varieties } \\
\text { during post-kharif season of 2013-2015 in the Central Research Farm, Gayeshpur, Bidhan } \\
\text { Chandra Krishi Viswavidyalaya. The morphological characteristics of brinjal leaves are } \\
\begin{array}{l}\text { Brichome, Leaf } \\
\text { thickness. }\end{array}\end{array}$ \\
\hline Article Info & $\begin{array}{l}\text { associated with attraction, feeding and oviposition of the insect pests. In 2013-2015 } \\
\text { investigation, interaction between jassids incidence and morphological characteristics on } \\
\text { brinjal revealed that the population of jassids, whitefly, shoot and fruit borer, and } \\
\text { epilachna beetles was negatively correlated with leaf thickness and trichomes. The jassids, } \\
\text { whitefly, epilachna beetles population was negatively correlated with leaf area but the } \\
\text { aphid and shoot and fruit borer were positively correlated. Jassids, whitefly and aphids was } \\
\text { negatively correlated with coccinellids predators and spiders while, the population of shoot } \\
\text { Available Online: } \\
10 \text { November 2017 }\end{array}$ \\
\hline
\end{tabular}

\section{Introduction}

Brinjal or eggplant, Solanum melongena L. is one of the important vegetable crops grown in India and other parts of the world. Insect pests are the main constraint in the successful cultivation of brinjal. Among them, leafhopper and whitefly are cosmopolitan in distribution and are found wherever brinjal is grown. The use of resistance genotypes is familiar as the imperative tool for the biointensive pest management system. The morphological and physical characteristics of plants and fruits are associated with attraction, feeding and oviposition of the insect pests. Development of varieties resistant to the insect pests is an important strategy of integrated pest management (Bhatti et al., 1976). The identification of biophysical characteristics from insect resistant varieties is of most practical significance.

The degree of hair of trichome, on the leaves occurs in large numbers and plays a vital role in the plant defense particularly among phytophagous insects.

Uthamasamy (1985) found that the resistant varieties had more hairs than susceptible ones. Keeping in mind the seriousness of attack and the increasing incidence of the major insect pests on brinjal a humble attempt has been undertaken to find out the source of resistance and correlation of different morphological plant characteristics of different brinjal cultivars. 


\section{Materials and Methods}

A fields experiment was carried out during 2013-2015 at Central Research Farm of Bidhan Chandra Krishi Viswavidyalaya, Gayeshpur, Nadia, West Bengal. Twenty two (22) cultivars of brinjal were screened for their relative susceptibility to major insect pests. The plot size was $3 \mathrm{~m} \times 2.5 \mathrm{~m}$ with $60 \mathrm{~cm}$ and $50 \mathrm{~cm}$ spacing. The experiment was laid out in a Randomized block design with three replications. Ten leaves of almost similar age from each replication were plucked from each variety/genotype at peak infestation period of insect pests. The following observations were taken for morphological characteristics of different varieties/cultivars of brinjal: a) Leaf area (sq. cm) - measured by using graphpaper, b) Number of trichome on leaf lamina and midrib - the number of trichome per sq. $\mathrm{cm}$ of leaf of under surface (base, middle and tip portions) were counted with the aid of calibrated ocular grid under a dissecting microscope and c) Leaf thickness (mm) - the cross section of such leaves at three different parts of the lamina was taken and measured using stage and ocular micrometer. Several morphological characters of the twenty two varieties of brinjal were correlated each with the number of major insects.

\section{Results and Discussion}

The morphological characteristics of brinjal leaves are associated with attraction, feeding and oviposition of the insect pests. The effect of leaf morphological characters of brinjal on different varieties have been recorded during 2013-2015 and presented in Table 1. In the present study revealed that the mean leaf thickness in different varieties ranged between 0.26 to $0.80 \mathrm{~mm}$. The varieties Sada Jhuri Begun $(0.80 \mathrm{~mm})$ was recorded highest leaf thickness followed by the varieties Punjab Sadabahar and Garia Begun (0.57
$\mathrm{mm})$.While, the lowest leaf thickness was observed on the varieties BCB-50 $(0.26 \mathrm{~mm})$ followed by BCB-11 $(0.27 \mathrm{~mm})$ and $13 \mathrm{BRL}-2$ $(0.29 \mathrm{~mm})$.

The mean leaf area on different brinjal varieties ranged from 32.35 to $64.20 \mathrm{~cm}^{2}$. The highest leaf area was observed on the varieties Muktakeshi $\left(64.20 \mathrm{~cm}^{2}\right)$ at par with each varieties and followed by 13 BRL-6 (58.30 $\mathrm{cm}^{2}$ ) and on par with each other. The least leaf area was found on the varieties 13 BRL-2 $\left(32.35 \mathrm{~cm}^{2}\right)$ and 13 BRL-4 $\left(33.00 \mathrm{~cm}^{2}\right)$. The mean trichome density on different varieties ranged between 778.05 and1138.40 per $\mathrm{cm}^{2}$. The highest trichome density was recorded on the varieties 12 SPL-BL-7 (1138.40 per $\left.\mathrm{cm}^{2}\right)$ followed by the varieties 13 BRL-6 (11.4.63 per $\mathrm{cm}^{2}$ ) but the lowest trichomes density was observed on the varieties 13 BRL-4 (778.05 per $\mathrm{cm}^{2}$ ).

The present investigations are in partial agreement with the finding by Amin et al., (2014) who reported that the higher leaf area $\left(63.53 \mathrm{~cm}^{2} /\right.$ leaf $)$ and leaf trichome $(256.7 / 25$ $\mathrm{mm}^{2}$ ) had lower shoot and fruit infestation. Wagh et al., (2012) also reported that the mean trichome density of leaf surface recorded in different brinjal genotypes ranged from 458.67 to 1192.67 per $\mathrm{cm} 2$ and maximum trichome density was found in less susceptible genotypes. The earlier results reported by Naqvi et al., (2008) specify the trichome density in the range of 550.5 to 1068.5 per $\mathrm{cm} 2$, the leaf area ranged 68.8$22.9 \mathrm{~cm}^{2}$ and leaf thickness ranged 0.343 $0.157 \mathrm{~mm}$ from thirteen (13) brinjal varieties.

\section{Correlation between insect pests of brinjal with leaf morphological characteristics of brinjal}

In the present studies, the leaf characters viz., leaf thickness, leaf area and trichomes density of leaves of 22 brinjal varieties were 
correlated with insect pests population, so that the promising brinjal varieties can be identified for future benefit. Weekly average of the screening incidence of insect pests population during 2013-2014 were analyzed and correlated on Table 2.

\section{Jassid, Amarasca biguttula biguttula}

Interaction between jassids incidence and morphological characteristics on brinjal revealed the population of jassids showed significantly negatively correlated with leaf thickness $(-0.431)$, while the leaf area $(-0.703)$ and trichomes density (-0.569) showed significantly negative correlation. The variation in population of jassids observed about $79 \%$ was due to all the leaf morphological characteristics (Table 2).

According to Naqvi et al., (2008) who reported that the leaf area, leaf thickness exerted no effect on leafhopper population, while trichome density had negative correlation. However, Giekwad et al., (1991) reported positive correlation between thickness of leaf and leaf area with leafhopper infestation. The most resistant varieties with longer more numerous and more branched trichomes and significantly correlated with leafhopper (Lit and Bernardo, 1990).

Table.1 Morphological leaf characters in different brinjal varieties/ genotypes

\begin{tabular}{|c|c|c|c|}
\hline Varieties & $\begin{array}{c}\text { Leaf thickness } \\
\text { (mm) }\end{array}$ & $\begin{array}{l}\text { Leaf area } \\
\left(\mathrm{cm}^{2}\right)\end{array}$ & 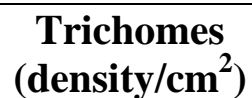 \\
\hline 13BRL-1 & 0.45 & 48.20 & 788.45 \\
\hline 13BRL-2 & 0.29 & 32.35 & 942.10 \\
\hline 13BRL-3 & 0.46 & 43.80 & 852.35 \\
\hline 13BRL-4 & 0.31 & 33.00 & 778.05 \\
\hline 13BRL-5 & 0.44 & 43.80 & 880.00 \\
\hline 13BRL-6 & 0.51 & 58.30 & 1104.63 \\
\hline Punjab Sadabahar & 0.57 & 46.90 & 993.05 \\
\hline Kashi Taru & 0.41 & 40.00 & 825.35 \\
\hline 12SPL-BL-1 & 0.31 & 47.25 & 877.20 \\
\hline 12SPL-BL-2 & 0.34 & 41.65 & 873.50 \\
\hline 12SPL-BL-4 & 0.41 & 45.70 & 951.65 \\
\hline 12SPL-BL-5 & 0.48 & 40.00 & 871.85 \\
\hline 12 SPL-BL-7 & 0.46 & 57.95 & 1138.40 \\
\hline BCB-11 & 0.27 & 49.90 & 793.70 \\
\hline BCB-30 & 0.49 & 52.15 & 874.95 \\
\hline BCB-50 & 0.26 & 56.40 & 832.40 \\
\hline Garia Begun & 0.57 & 44.00 & 964.80 \\
\hline Sada Jhuri Begun & 0.80 & 43.00 & 878.60 \\
\hline Muktakeshi & 0.52 & 64.20 & 814.55 \\
\hline Punjab Round & 0.36 & 40.95 & 863.20 \\
\hline Punjab Barshati & 0.29 & 40.10 & 933.45 \\
\hline Makra & 0.48 & 49.25 & 895.10 \\
\hline SE.m & 0.06 & 5.39 & 67.98 \\
\hline CD at $5 \%$ & 0.18 & 15.40 & 194.04 \\
\hline
\end{tabular}


Table.2 Correlations between insect pests with leaf morphological characteristics of brinjal

\begin{tabular}{|l|l|l|l|l|l|}
\hline \multicolumn{1}{|c|}{$\begin{array}{c}\text { Insect pests/ } \\
\text { Natural enemies }\end{array}$} & $\begin{array}{c}\text { Leaf } \\
\text { thick }\end{array}$ & $\begin{array}{c}\text { Leaf } \\
\text { area }\end{array}$ & Trichomes & \multicolumn{1}{|c|}{$\mathbf{R}^{\mathbf{2}}$} & \multicolumn{1}{c|}{ Regression equation } \\
\hline Jassids & $-.431 *$ & $-.703 * *$ & $-.569 * *$ & 0.791 & $\mathrm{Y}=7.88-.01 \mathrm{X}_{1}-.05 \mathrm{X}_{2}-1.21 \mathrm{X}_{3}$ \\
\hline Whitefly & -.352 & -.051 & -.356 & 0.696 & $\mathrm{Y}=-4.11-.02 \mathrm{X}_{1}-.81 \mathrm{X}_{2}-4.82 \mathrm{X}_{3}$ \\
\hline Aphid & -.371 & .041 & -.019 & 0.825 & $\mathrm{Y}=-1.29-.51 \mathrm{X}_{1}-1.09 \mathrm{X}_{2}-2.81 \mathrm{X}_{3}$ \\
\hline Shoot and fruit borer & -.190 & .033 & -.204 & 0.703 & $\mathrm{Y}=-3.21-2.01 \mathrm{X}_{1}-.85 \mathrm{X}_{2}-2.19 \mathrm{X}_{3}$ \\
\hline Leafrollers & -.101 & .030 & -.304 & 0.731 & $\mathrm{Y}=-2.82-1.08 \mathrm{X}_{1}-2.19 \mathrm{X}_{2}-1.81 \mathrm{X}_{3}$ \\
\hline Epilachna beetles & -.307 & -.086 & $-.447 *$ & 0.400 & $\mathrm{Y}=.85-0.29 \mathrm{X}_{1}-0.14 \mathrm{X}_{2}-2.81 \mathrm{X}_{3}$ \\
\hline
\end{tabular}

$*$ Significant at the 0.05 level (2-tailed), **significant at the 0.01 level (2-tailed).

Table.3 Correlations between insect pests with their natural enemies of brinjal

\begin{tabular}{|l|l|l|l|l|}
\hline \multicolumn{1}{|c|}{$\begin{array}{c}\text { Insect pests/ } \\
\text { Natural enemies }\end{array}$} & Coccinellid & \multicolumn{1}{c|}{ Spider } & \multicolumn{1}{|c|}{$\mathbf{R}^{\mathbf{2}}$} & \multicolumn{1}{c|}{ Regression equation } \\
\hline Jassids & -0.208 & $-0.409^{*}$ & 0.780 & $\mathrm{Y}=7.88-.05 \mathrm{X}_{1}-2.02 \mathrm{X}_{2}$ \\
\hline Whitefly & -0.032 & -0.197 & 0.705 & $\mathrm{Y}=-4.11-.08 \mathrm{X}_{1}-3.05 \mathrm{X}_{2}$ \\
\hline Aphid & -0.061 & -0.202 & 0.830 & $\mathrm{Y}=-1.29-.05 \mathrm{X}_{1}-1.15 \mathrm{X}_{2}$ \\
\hline Shoot and fruit borer & $.439^{*}$ & -0.026 & 0.690 & $\mathrm{Y}=-3.21-.09 \mathrm{X}_{1}-.04 \mathrm{X}_{2}$ \\
\hline Leafrollers & 0.421 & -0.097 & 0.721 & $\mathrm{Y}=-2.82-2.03 \mathrm{X}_{1}-.09 \mathrm{X}_{2}$ \\
\hline Epilachna beetles & $.616^{* *}$ & 0.154 & 0.390 & $\mathrm{Y}=.85-3.12 \mathrm{X}_{1}-.07 \mathrm{X}_{2}$ \\
\hline
\end{tabular}

* Significant at the 0.05 level (2-tailed), **significant at the 0.01 level (2-tailed).

\section{Whiteflies, Bemisia tabaci}

In 2013-2014, interaction studies between the whiteflies incidence and morphological characteristics on brinjal showed that the leaf thickness, leaf area and trichomes density had negatively non-significant correlation with whiteflies population.

The variation in population of whiteflies observed about $69 \%$ was due to all the leaf morphological characteristics (Table 2). The present findings are in agreement with Naqvi et al., (2008) who reported that the leaf area had positive significant effect on whitefly population, whereas leaf thickness, trichome density had no significant effect. Soundarajan and Baskaran (2001) reported negative significant correlation between trichome density and whitefly population are in supportive with the present findings.

\section{Aphids, Aphis gossypii}

The population of aphids revealed a negatively non- significant correlation with leaf thickness and trichomes density. But, showed positively non-significant correlation with leaf area. The variation in population of aphids observed about $82 \%$ was due to all the leaf morphological characteristics (Table 2).

Ishaque and Choudhuri (1984) reported that they had high positive correlation between the leaf area of the varieties and the degree of susceptibility. They also found less susceptible varieties had thick and closely placed leaf trichome. 


\section{Brinjal shoot and fruit borer, Leucinodes} orbonalis

The population of brinjal shoots and fruit borer revealed that the leaf thickness $(-0.190)$ and trichomes density (-0.204) was negatively non-significant correlation but the leaf area $(+0.033)$ was found positively non-significant correlated. The variation in population of shoot and fruit borer observed about $70 \%$ was due to all the leaf morphological characteristics (Table 2).Wagh et al., (2012) observed that the shoot thickness showed strong and positive correlation $(\mathrm{r}=0.632)$ in relation to incidence of shoot borer. Javed $e t$ al., (2011) reported that strong and negative correlation between trichome density and infestation of $L$. orbonalis which are in agreement with present study.

\section{Leaf roller, Eublemma olivacea}

During 2013-2014, the leaf roller population showed negatively non-significant correlation with the leaf thickness and trichomes density. While, the leaf area was positive correlated. The variation in population of leaf roller observed about $73 \%$ was due to all the leaf morphological characteristics (Table 2).

\section{Epilachna beetles, Epilachna vigintioctopunctata}

The epilachna beetles population was negatively non-significant correlated with the leaf thickness $(-0.307)$ and leaf area (-0.086) but negatively significantly correlated with trichomes density (-0.447). The variation in population of epilachna beetles observed about $40 \%$ was due to all the leaf morphological characteristics (Table 2).Wagh et al., (2012) reported that the maximum trichome density was found in less susceptible genotypes. Ishaque and Chowdahary's (1984) supported that they had high positive correlation between the leaf area of the varieties and the degree of susceptibility. They also found less susceptible varieties had thick and closely placed leaf trichome.

\section{Correlation between insect pests with their natural enemies of brinjal}

\section{Coccinellid predators}

The population of coccinellid predators was negatively correlated with the population of jassids (-0.208), whiteflies (-0.032) and aphid incidence $(-0.061)$. While brinjal shoot and fruit borer $(+0.439)$ and epilachna beetle $(+0.616)$ were significantly positively correlated. But, the population of leafroller $(+0.421)$ was positively non-significant correlated (Table 3).

\section{Spider}

In 2013-2014, the spiders showed negatively significant correlation with jassids but the whiteflies, aphids, brinjal shoot and fruit borer and leafroller incidences was negatively non-significant correlated. While, epilachna incidence $(+0.154)$ was positively nonsignificantly correlation with the population of spiders (Table 3 ).

The variation in population of insect pests of brinjal observed about $39 \%$ to $83 \%$ was due to their natural enemies. According to Vishav et al., (2014) supported that the conservation of natural enemies will help in suppressing the E. vigintiocpunctata population in brinjal. Kalaichelvi (2008) reported that the natural enemies population was found to have direct correlation with sucking pest population.

\section{References}

Amin, S.M.R.; Alam, M.Z.; Rahman, M.M.; Hossain, M.M. and Mian, I.H. 2014. Study on morphological characteristics of leaves, shoots and fruits of selected 
brinjal varieties/lines influencing brinjal shoot and fruit borer infestation. International Journal of Economic Plants.1 (1):001-008.

Bhatti, M. A., M. Saeed, N. Chatta and S. Iqbal. 1976. Hostplant resistance and importance to insect population suppression in cotton crop. Proc. Cott. Prod. Seminar, ESSO, Pak. Fertilizer Co. Ltd. pp. 132-142.

Giekwad, B. P.; Darakar, K. S. and Chavan, U. D. 1991.Varietal reaction of eggplant against leafhopper. Journal of Maharashtra Agricultura University. 16: 354-356.

Isahaque, N. M. M. and Chaudhuri, R. P., 1984.Larval development behavior of Leucinodes orbonalis Guen. reared on some brinjal varieties. Journal of Research, Assam Agricultural University.5: 93-97.

Javed, H.; Ata-ul-mohsin; Aslam, M.; Naeem, M.; Amjad, M. and Mahmood, T. 2011.Relationship between morphological characters of different aubergine cultivars and fruit infestation by Leucinodes orbonalis Guenee. Pakistan Journal of Botany.43 (4): 2023-2028.

Kalaichelvi, K. (2008). Effect of plant spacing and fertilizer levels on insect pests in BT cotton hybrids.Indian Journal of Entomology. 70(4): 356-59.

Lit,M.C. and Bernardo,E.N.1990.Mechanism of resistance of eggplant (Solanum melongena Linn.) to the cotton leafhopper, Amrasca biguttula (Ishida)
II. Morphological and biochemical factors associated with resistance. Philippine Journal of Crop Science.15 (2): 79-84.

Naqvi, A.R; Pareek, B.L; Nanda, U.S. and Mitharwal, B.S. 2008. Leaf morphology and biochemical studies on different varietie of brinjal in relation to major sucking insect pests. Indian Journal of Plant Protection.36 (2): 245-248.

Soundarajan R. P. and Baskaran P. 2001. Mechanism of resistance in brinjal (Solanum melongenaL.) to whitefly, Bemisia tabaci (Gennadisus L.). Madras Agricultural Journal.88:657659.

Uthamasamy, S. 1985. Influence of leaf hairiness on the resistance of bhendi or lady,s finger, Abelmoschus esculentus(L.) Moench, to the leafhopper, Amrasca devastans (Dist.). Trop. Pest Manag. 31:294-295.

Vishav, V. S. J.; Hafeez, A.; Devinder, S.; Kuldeep, S. and Suheel, A. G. 2014. Natural enemies associated with Epilachna vigintiopunctata (F.) on brinjal. Indian Journal of Entomology.76 (4):356-358.

Wagh, S.S; Pawar, D.B; Chandele, A.G. and Ukey, N.S. 2012. Biophysical mechanisms of resistance to brinjal shoot and fruit borer, Leucinodes orbonalis Guenee in brinjal. Pest Management in Horticulture Ecosystem.18 (1):54-59.

\section{How to cite this article:}

Bindu, S.P. and Pramanik, A. 2017. Effect of Leaf Characteristics on Different Brinjal Genotypes and their Correlation on Insects Pests Infestation. Int.J.Curr.Microbiol.App.Sci. 6(11): 3752-3757. doi: https://doi.org/10.20546/ijcmas.2017.611.439 